\title{
Editorial
}

\section{Coastal Morphology Assessment and Coastal Protection}

\author{
Yoshimichi Yamamoto (D)
}

Department of Civil Engineering, Tokai University, Kanagawa 259-1292, Japan; yo-yamamo@tokai.ac.jp

\section{Introduction}

Sediment-collecting in rivers and seas to secure a large amount of aggregate reduces the supply of earth and sand to coasts. Dams and breakwaters constructed in various places impede the transportation of earth and sand as a side effect. Furthermore, the maintenance dredging of dam lakes and waterways will also disrupt the supply of sediment to coasts if the dredged sediment is not released back to the water system. Due to these development activities, coastal erosion has become a serious problem on many beaches around the world. Moreover, due to excessive industrial activities by human beings, the exacerbation of natural disasters caused by global warming is becoming a real problem. In addition, because great earthquakes with a magnitude of 9 or more have occurred about three times per 100 years at boundaries of the Pacific Crust Plate and the Nazca Crust Plate since 1700, the possibility of losing many lives and assets in the Pacific coastal areas due to a huge tsunami caused by a great earthquake should also not be underestimated. Therefore, research into the prevention and mitigation of coastal erosion and coastal disasters is becoming increasingly important.

In this Special Issue, five studies on coastal erosion and coastal disaster prevention resulting from large waves and tsunamis were collected to contribute to the technological progress in this field.

Citation: Yamamoto, Y. Coastal Morphology Assessment and Coastal Protection. J. Mar. Sci. Eng. 2021, 9, 713. https://doi.org/10.3390/ jmse9070713

Received: 2 June 2021

\section{Coastal Beach Change by Large Waves}

Since around 1960, when the coastal erosion problem became more serious, many researchers have participated in research into beach topography changes, and many practical numerical models for forecasting beach deformation have emerged. (XBeach model [1], DELFT3D Model [2], 3D Coupled Fluid-Structure-Sediment Interaction Model [3], etc.). However, when performing a long-term prediction using a 3D or horizontal 2D numerical model, if the external force for the entire period is input, the calculation time becomes very long. Therefore, it is necessary to select a limited number of external forces that are dominant against topographical changes to save calculation time. From this perspective, it is important to elucidate the topographical change phenomenon of a target coast from the analysis using long-term information on topographical changes and external forces. Nuyts et al. [4] clarified the trends of topographical changes in the Rossbeigh coastal barrier in Dingle Bay, Ireland, using detailed analyses of 19-year data from the global navigation satellite system, bathymetry surveying, and an external force observation system. Moreover, Kelpšaite-Rimkienè et al. [5] revealed the characteristics of the cross-shore profile change in the Palanga coast of the East Baltic Sea through the skillful analysis of topographic survey data and wind data using K-means Clustering Technique, and calculation of the cross-shore sediment transport rate.

Furthermore, since gravel barrier beaches are important as natural breakwaters, Ions et al. [6] predicted the amount of erosion and overwash per unit length on the beach, caused by important combinations of external forces using the $\mathrm{X}$ Beach model on the gravel barrier beach of Hurst Castle Spit in UK. Then, they organized these simulated values by the barrier inertia parameter (=the pre-storm barrier cross sectional area $\times$ the initial 
barrier freeboard/the cube of the incident wave height) and created calculation charts to obtain the amount of erosion and overwash per unit length.

\section{Coastal Disasters by Tsunamis}

Calculation methods for tsunami inundation and topographical changes due to tsunamis has also progressed rapidly since around 1990, when data began to increase due to the spread of observation technology, and 3D prediction numerical models have emerged (DELFT3D model [2], 3D Coupled Fluid-Structure-Sediment Interaction Model [7], etc.). However, due to the large geographic areas which need to be modelled, the computational costs of 3D tsunami simulations can be extremely high. Therefore, simulations using an ordinary computer becomes infeasible. Ahmadi et al. [8] improved the prediction method technique using a numerical model of horizontal 2D inundation and topographical change that can be executed by an ordinary computer. The main sediment movement of topographical changes is "bed load", and the coefficients of formulae to calculate the bed load must be determined in advance by verification simulations based on actual measurement data of the target coast. However, without the actual measurement data, it became difficult to numerically reproduce topographical changes. Therefore, they conducted vertical 2D hydraulic experiments with models that were as large as possible to create calculation charts that can easily determine the coefficient of a formula for calculating the bed load. In addition, they proposed diagrams that can easily determine the threshold value of the width of columns, where individual buildings collapse due to the tsunami, using inundation depth data obtained from the calculation results of the horizontal 2D numerical model.

In the case of a huge tsunami, because the inundation area becomes vast and the amount of generated drifting objects become enormous, it is also important to provide methods that can correctly evaluate the impact force when a drifting object hits a structure. Therefore, Yamamoto et al. [9] proposed appropriate impact force calculation formulae for each type of drifting object, based on the correlation examination using the impact force data from collision experiments with large models.

\section{Conclusions}

This Special Issue has introduced two analysis methods using the data of coastal topography changes and external forces, which are useful for grasping the characteristics of topography changes due to large waves and examining coastal protection measures, and an effective use method of the Xbeach model to obtain calculation charts that contribute to coastal protection. Moreover, this Special Issue has introduced a method that can predict the wide-area topographical changes and building destruction caused by a huge tsunami relatively easily, and appropriate formulae for estimating the impact force for each driftage type, in order to prevent the structural destruction caused by drifting objects generated in large numbers by the huge tsunami. The authors sincerely hope that this Special Issue will be useful for coastal disaster prevention.

Funding: This editorial received no external funding.

Institutional Review Board Statement: Not applicable.

Informed Consent Statement: Not applicable.

Acknowledgments: All contributing authors and reviewers are thanked for their efforts.

Conflicts of Interest: The author declared no conflict of interest.

\section{References}

1. UNESCO-IHE, Deltares, Delft University of Technology, and University of Miami. Available online: https:/ / oss.deltares.nl/web / xbeach/home (accessed on 25 June 2021).

2. Deltares, and Delft University of Technology. Available online: https:/ / oss.deltares.nl/web/delft3d (accessed on 25 June 2021).

3. Tomoaki, N.; Solomon, C.Y.; Norimi, M. Development of Three-Dimensional Coupled Fluid-Structure-Sediment Interaction Model and its Application to Local Scour around Submerged Object. J. Jpn. Soc. Civ. Eng. B2 2010, 66, 406-410. (In Japanese) 
4. Siegmund, N.; Michael, O.; Jimmy, M. Monitoring the Morphodynamic Cannibalization of the Rossbeigh Coastal Barrier and Dune System over a 19-Year Period (2001-2019). J. Mar. Sci. Eng. 2020, 8, 421. [CrossRef]

5. Kelpšaitè-Rimkienè, L.; Parnell, K.E.; Žaromskis, R.; Kondrat, V. Cross-Shore Profile Evolution after an Extreme Erosion EventPalanga, Lithuania. J. Mar. Sci. Eng. 2021, 9, 38. [CrossRef]

6. Ions, K.; Karunarathna, H.; Reeve, D.E.; Pender, D. Gravel Barrier Beach Morphodynamic Response to Extreme Conditions. J. Mar. Sci. Eng. 2021, 9, 135. [CrossRef]

7. Nakamura, T.; Mizutani, N. Numerical Analysis of Tsunami Overflow over a Coastal Dike and Local Scouring at the Toe of its Landward Slope. J. Jpn. Soc. Civ. Eng. B3 2014, 70, I_516-I_521. (In Japanese)

8. Ahmadi, S.M.; Yamamoto, Y.; Ca, V.T. Rational Evaluation Methods of Topographical Change and Building Destruction in the Inundation Area by a Huge Tsunami. J. Mar. Sci. Eng. 2020, 8, 762. [CrossRef]

9. Yamamoto, Y.; Kozono, Y.; Mas, E.; Murase, F.; Nishioka, Y.; Okinaga, T.; Takeda, M. Applicability of Calculation Formulae of Impact Force by Tsunami Driftage. J. Mar. Sci. Eng. 2021, 9, 493. [CrossRef] 